\title{
An Investigation of The Relationship Between Ecological and Materialistic Values of Turkish Teacher Candidates
}

\author{
Nevin ÖZDEMİR ${ }^{1}$ \\ Ondokuz Mayıs University, Samsun
}

TURKEY

${ }^{1}$ Assoc. Prof. Dr. Department of Social Science and Turkish Education, Ondokuz Mayıs University Education Faculty, Samsun, Turkey. nvnozdmr@hotmail.com, ORCID: 0000-0001-9408-3238

\begin{abstract}
Materialistic values are important factors that guide individuals' philosophy of life. For this reason, it is thought that individuals' environmental attitudes and ecological world views may be related to their materialistic values. Therefore, the purpose of this study is to examine whether there is a relationship between the materialistic and ecological values of prospective teachers. The study sample consists of 685 prospective teachers studying in a Faculty of Education at a university in northern Turkey. In the 2016-2017 academic year, prospective teachers who participated in this study were studying in first and last grade level of five different departments: Social Studies $(n=115)$; Science $(n=149)$; primary education ( $n=151)$; Mathematics $(n=134)$; and pre-school teaching $(n=136)$. A questionnaire including the New Ecological Paradigm Scale (NEPS), and the Material Values Scale (MVS) was used to gather data. The mean scores of both scales were based on the interpretation of the research findings, and the relationship between materialistic and environmental values of sample and variables such as gender, grade level, the field of teaching, and environmental education were examined. The correlations among materialistic and environmental values and environmental education were also examined. The results of the study demonstrated that prospective teachers have high levels of ecocentric values and moderate levels of materialistic values; also, these values have significant relations with some of the variables. The findings indicated there were negative or positive weak correlations between some variables.
\end{abstract}

\section{Keywords}

New Environmental Paradigm Scale, Materialism, Prospective Teachers, Environmental Education 
From the 19th Century to the 20th Century, several developments such as industrialization, urbanization, tourism, transportation and population growth have changed people's lifestyles. Such developments are due to the influence of innovations in science and technology. Nowadays, due to the ongoing nature of development, many changes have occurred to the production and consumption habits of people. Through various channels, such as media in particular, people living in both developed and developing countries have been virtually encouraged to produce more and increase their consumption. Due to this rapid increase in supply and demand, the pressure of humans on the natural environment has gradually increased, and the natural environment has become increasingly degraded (Atasoy, 2006).

The fact that environmental problems have reached dimensions threatening the whole of humanity has revealed the necessity for discussing these problems across international platforms. In particular, the importance of environmental education at all levels of education has been highlighted by representatives from a great number of international and intergovernmental organizations and agencies such as the 1971 Environmental Education Conference of the International Union for the Conservation of Nature and Natural Resources (IUCN); the 1975 International Belgrade Workshop; the 1977 Tbilisi Conference; and 1992 United Nations Conference on Environment and Development, Earth Summit (Carter \& Simmons, 2010; Palmer, 2002; Wheeler, 1985). The UNESCO-UNEP International Environmental Education Program has described the preparation of teachers as "the priority of priorities" for action to improve the effectiveness of environmental education (UNESCO-UNEP, 1990). Furthermore, the objectives of environmental education as defined by the Tbilisi Intergovernmental Conference on Environmental Education in 1977 have been declared as awareness, sensitivity, attitudes, skills, participation (Hungerford \& Volk, 1990). Following such developments, certain topics including environmental knowledge, environmental awareness, environmental attitudes, environmental ethics, and environmental values have become popular areas of interest for researchers who work across both the sciences and social sciences (Rickinson, 2001; Wray-Lake, Flanagan, \& Osgood, 2010).

The term sustainable development has been talked about frequently since the 1960s and became a popular concept in the 1987 Brundtland Report. The Brundtland Commission's brief definition of sustainable development is understood as the ability to make development sustainable, that is, to ensure the needs of the present generation are met without compromising the ability of future generations to meet their own needs" (United Nations, 1987). The connotations of both of root words in this definition, "sustainable" and "development", are generally viewed as quite positive by most people. The combination of such words imbues the understanding that sustainability is a worthwhile value and goal, and is a powerful feature in diverse and conflict social contexts (Robert, Parris, \& Leiserowitz, 2005). 
It was pointed out that universities, and especially teacher training institutions can be highly effective for environmental education (Bentham, Sinnes, \& Gjøtterud, 2015). In the United Nations Decade of Education for Sustainable Development (2005 - 2014), it is emphasized that sustainable development issues should be integrated into education in a holistic and interdisciplinary manner (Achim, Stan, \& Dragolea, 2018; Wals, 2014). One of the objectives of Education for Sustainable Development has focused on incorporating Sustainable Development into ordinary educational activities and reorienting curricula from pre-school to university (UNESCO, 2005). Furthermore, environmental education courses have been added to the curriculum of many universities or schools (Kilbourne \& Carlson, 2008). It is thought that environmental education in school curricula and hence the teachers who undertake training in environmental education have an important role to play in developing attitudes and behaviors of students towards the environment (Stevenson, 2007). In recent years, according to the results of discussions between scholars and researchers about the "nature of environmental education", it is suggested that environmental education should focus on environmental education for sustainability (EEFS) to improve the quality of life for all citizens (Tilbury, 1993). Consequently, numerous theories and models have been developed about how environmental education should be planned, developed and implemented.

Over the last 30 years, many psychologists and sociologists have tried to explain the roots of the complex interactions occurring between humans and the environment. Numerous researchers have investigated a variety of variables which are hypothesized to be associated with responsible environmental behavior (Kollmuss \& Agyeman, 2002). Consequently, many researchers who are many researches interested in this subject have developed a series of theories and models. For example, the theory of reasoned action (Fishbein \& Ajzen, 1980); the model of responsible environmental behavior (Hines, Hungerford, \& Tomera, 1987), the model of ecological behavior created by Fietkau and Kessel in 1981 (Shamuganathan \& Karpudewan, 2015). In the model created by Blake (1999), it was defined as individuality, responsibility, and practicality that three barriers between environmental concern and action.

The oldest and simplest models of pro-environmental behavior were based on the fact that the increase in environmental knowledge leads to increased environmental awareness and interest. As a result, pro-environmental behaviors could occur in individuals (Hungerford \& Volk, 1990; Kollmuss \& Agyeman, 2002). In other words, it was assumed that education about the environment leads to proenvironmental behavior (Burgess, Harrison, \& Filius, 1998). Although the findings of many previous studies about environmental education supported this idea that environmental awareness and interest showed a positive development since the 1970s, some studies draw attention to the mismatch between environmental attitudes and behaviors (Albayrak, Caber, Moutinho, \& Herstein, 2011; Alwitt \& Pitts, 1996; Kilbourne \& Carlson, 2008). This means that individuals with proenvironmental attitudes may not always have pro-environmental behaviors 
(Kollmuss \& Agyeman, 2002; Wray-Lake et al., 2010). Many researchers have tried to explain such a gap between attitudes and behaviors; and Rajecki (1982) defined four causes: direct versus indirect experience; normative influences such as social norms, cultural traditions, and family customs influence and shape people's attitudes; temporal discrepancy, which refers to the fact that people's attitudes change over time; and attitude-behavior measurement.

Kollmuss and Agyeman (2002) reported that all of the models developed to explain the attitude-action gap and investigate the barriers towards proenvironmental behavior, have some validity in certain circumstances. Also, it was pointed out that there are commonalities, contradictions, and omissions that can be found in the different models (Kollmuss \& Agyeman, 2002). Researchers distinguished have the specific factors established as having some influence (positive or negative) on the models of pro-environmental behavior. Such factors were listed as "demographic factors, external factors (for example, institutional, economic, social, and cultural factors) and internal factors (for example, motivation, environmental knowledge, awareness, values, attitudes, emotion, locus of control, responsibilities, and priorities)" (Kollmuss \& Agyeman, 2002, p. 248).

Environmental values amongst the above factors were one of the research topics of environmental psychology that emerged primarily in the US in the 1960s (Bonnes \& Secchiaroli, 1995), and this term refers to value judgments guiding how people interpret nature. This study focused on values and attitudes that have a very important role in determining pro-environmental behavior. Callicott $(2004$, p. 36) stated that "environmental values are located at two ends: intrinsic and instrumental. An instrumental value approach forms the basis of a mechanistic worldview and anthropocentric environmental values, and is based on the belief that nature exists for the benefit of humans." According to an instrumental approach, all beings or other lifeforms in nature are valuable and important to the extent of their benefits to people. In contrast, the intrinsic value approach forms the basis of an ecological worldview and eco-centric environmental values, where all the living beings in nature are valuable and their values come from their existence (Justus, Colyvan, Regan, \& Maguire, 2009). Values specific for this field are determiners of environmental attitudes and behaviors ranging from vehicle use to recycling (Barr, 2007).

There are also findings to say that individual values, such as materialism, can be effective in shaping environmental attitudes and behaviors. In the Oxford English Dictionary, materialism is defined as an emphasis on or preference for that which is material, at the expense of spiritual or other values ("Materialism", n.d.). Richins and Dawson (1992) defined materialism as an individual value, which included an emphasis on material assets. Materialism includes features such as indulgence and status, jealousy, insensitivity to and around social issues, selfishness, lack of principle, insecurity, desire to own and discrimination (Richins \& Fournier, 1991). Also, Belk (1985) defined materialism as the importance a consumer attaches to 
property acquisition. For people with strong materialist tendencies, the acquisition of property is the main purpose of their lives, and this is seen as the source of satisfaction and dissatisfaction. According to the results of the same studies conducted on environmental issues within the marketing discipline, it was revealed that consumption patterns, materialistic tendencies or value judgments defining the dominant social paradigm of western industrial societies have a negative influence on environmentally friendly behaviors (Wals, 2014). For this reason, the influence of materialism on environmental degradation, environmental attitudes, and behaviors should be closely examined (Kilbourne \& Pickett, 2008).

It is also stressed that "materialistic values are important to consider concerning environmental attitudes and behavior for two reasons: first, there is considerable theoretical and empirical support that this particular value may be negatively related to environmental outcomes, and second, it is an individual difference which may be more readily influenced than personality variables" (Hurst, Dittmar, Bond, and Kasser 2013, p. 257).

In this context, it would be appropriate to consider the materialist values of the individuals. Although a negative correlation has been put forward between individuals' materialistic tendencies or values and their environmental attitudes and behaviors by some studies (Hirsh \& Dolderman, 2007; Hurst et al., 2013; Kemmelmeier, Krol, \& Kim, 2002), However, it is noteworthy there is a lack of literature on the correlation between environmental values and materialistic values of teachers and prospective teachers. This is important because teachers and prospective teachers have an important role to play in the development of future generations as eco-friendly citizens. Consequently, the present study was conducted on the correlation between the environmental values and materialistic values of prospective teachers in Turkey who are studying in different fields of teaching. Also, the current study focuses on the following questions:

1. Is there any difference between the mean scores of environmental values and materialistic values of prospective teachers in terms of the following variables: gender, year of study, the field of teaching, and environmental education?

2. What is the correlation between the environmental values and materialist values of prospective teachers?

\section{Methodology}

\section{Research Design}

This study was conducted as a survey study in which "an attempt to obtain data from members of a population to determine the current status of that population concerning one or more variables" (Fraenkel, Wallen, \& Hyun, 1993, p. 17). This type of research can be conducted with a specific target group or across multiple groups along with comparative analysis. A correlation study was conducted. The correlation research used one of the primary quantitative research methods to correlate two or more variables using mathematical analysis methods (Kaptan, 1998; Karasar, 2002; Sönmez \& Alacapınar, 2016). Accordingly, the current study 
focused on whether or not there were significant differences in the scale dimensions of some demographic variables, and the correlation that may or may not exist between the environmental values and materialistic values of prospective teachers who participated in the study.

\section{Study Group}

The study sample was determined by a random sampling method. The study sample consisted of prospective teachers who volunteered to answer the paper survey used as a data collection tool. A total of 685 respondents were studying in different departments of the Faculty of Education. Demographic data of the sample are summarized in Table 1.

Table 1

The Demographic Characteristics of The Study Group

\begin{tabular}{llll}
\hline Demography & Groups & F & \% \\
\hline \multirow{2}{*}{ Gender } & Male & 182 & 27 \\
& Female & 503 & 73 \\
& 1 & 336 & 49 \\
\multirow{5}{*}{ Departmente level } & 4 & 349 & 51 \\
& Social studies teachings (SST) & 115 & 17 \\
& Science teaching (ST) & 149 & 21 \\
& Primary school teaching (PST) & 151 & 22 \\
& Mathematic teaching (MT) & 134 & 20 \\
& Preschool teaching (PT) & 136 & 20 \\
& Total & 685 & 100 \\
\hline
\end{tabular}

\section{Data Collection Tool}

A paper survey consisting of three parts was used as a data collection tool. The first part of this survey contained personal information such as gender, year of study, the field of teaching (or department). In this section there was also a question about whether or not the participants had previously taken any environmental education course.

In the second part of the survey, there was the New Ecological Paradigm Scale (NEPS) which enabled us to make a distinction between an individuals' eco-centric and anthropocentric environmental views. The NEPS was first developed by Dunlap and Van Liere in 1978 (Dunlap \& Van Liere, 1978). Later in 2000 it was revised to improve the psychometric properties of the scale (Dunlap, Liere, Mertig, and Jones, 2000). Items in the NEPS emphasized the progress of impact on the new ecological world, the prevailing social paradigm, the use of technology, and the environment for growth. The revised scale was then called the New Ecological Paradigm Scale and it was translated into Turkish by some researchers, with validity and reliability studies being conducted with different samples at different times (Aytaç \& Öngen, 2012; Erdoğan, 2009; Erkal, Kılıç, \& Sahin, 2012). Of these 15 items, 8 items are related to ecological eco-centric views, whereas 7 items are related to anthropocentric views. Due to the 5 point-Likert-type scale, scores in the eco-centric dimension of NEPS range from a minimum of 8 to a maximum of 40, whereas scores in the anthropocentric dimension of NEPS range from a minimum of 7 to a maximum of 35. If a participant has very strong eco-centric values, the participant will be able 
to take a maximum of 48 points, whereas if a participant has very strong anthropocentric values, the participant will be able to take a maximum of 42 points. The alpha co-efficient of NEPS was reported as .83 (Dunlap et al., 2000). For the current study, the Cronbach alpha co-efficient for eco-centric and anthropocentric dimensions of NEPS and the whole scale were found as $.69, .70$, and .72 respectively.

In the third part of the survey, there was the Materialist Value Scale (MVS) developed by Richins and Dawson (Richins \& Dawson, 1992). This scale includes a total of 18 items including the dimensions of centrality (items 1 to 6 ), success (items 7 to 13) and happiness (items 14 to 18). Researchers reported that "the seven centrality items produced alpha co-efficient between .71 and .75; the six-item success subscale alpha ranged from .74 to .78; and for the five happiness items, alpha was between .73 and .83 . When combined into a single scale, alpha for the 18 items varied between .80 to .88" (Richins \& Dawson, 1992, p. 310). The validity and reliability study of the Turkish version of MVS was conducted by Turan (2007). The researcher reported that the alpha co-efficient of the centrality, success, and happiness dimensions were $.77, .74$, and .72 respectively. The alpha for the 18 items was reported as .84. For the study at hand, alpha co-efficient were calculated as .82 for 18 items, and for these items' alpha ranged between .79 and .82. Also, the alpha co-efficient for success, centrality, and happiness sub-scales were calculated as .56, .74 , and .64 respectively.

\section{Data Evaluation}

The 5 point-Likert scale formats were used for both scales with response categories of strongly disagree $(S D=1)$, mildly disagree $(M D=2)$, unsure $(U=3)$, mildly agree $(\mathrm{MA}=4)$, and strongly agree $(\mathrm{SA}=5)$. However, 8 of the items in MVS (items $3,6,7,8,9,13,14,15)$ were reverse coded. The mean scores were taken into consideration in the interpretation of data. Therefore, if the mean scores are close to 1 it is understood that pre-service teachers' ecological values or materialist values are weak, whereas if the mean scores are close to 5, their ecological values or materialist value judgments are assumed to be strong. The Kolmogorov-Smirnov (KS) test was calculated to determine whether the data do not follow a normal distribution. As shown in Table 2, the test results indicated the data do not follow a normal distribution.

Table 2

The Kolmogorov-Smirnov (K-S) Test Results for the Overall Scales, and Sub-Dimensions

\begin{tabular}{llll}
\hline & Statistic & df & Sig. \\
\hline Eco-centric (EC) & .116 & 685 & .000 \\
Anthropocentric (AC) & .088 & 685 & .000 \\
Success (S) & .081 & 685 & .000 \\
Centrality (C) & .076 & 685 & .000 \\
Happiness (H) & .069 & 685 & .000 \\
NEPS Total & .116 & 685 & .000 \\
MVS Total & .065 & 685 & .000 \\
\hline
\end{tabular}


It was decided to use non-parametric tests based on the test result. The MannWhitney $U$ test was employed to determine whether the points of scales varied according to two independent variables such as gender, level of grade, and environmental education. The Kruskal Wallis $\mathrm{H}$ was used to determine whether the points varied according to the department of teaching. The correlation between the scale dimensions was determined by the Spearman Rho Correlation Coefficient (rho). Statistical calculations were based on a significance level of 0.05 . The mean scores of both scales were interpreted based on Tekin's formula (range extend/ number of groups) (Tekin, 1996) as follows: 1,00-1,80= strongly disagree (SD); $1,81-2,60=$ mildly disagree (MD); 2,61-3,40=unsure (U); 3,41-4,20= mildly agree (MA); 4,21-5,00= strongly agree (SA).

\section{Findings}

\section{The Results of NEPS And MVS Scores in Terms of Demographic Variables}

Table 3 displays descriptive statistic results of the scores of NEPS total, ecocentric (EC) and anthropocentric (AC) sub-scales of NEPS, and MVS total, success $(\mathrm{S})$, centrality (C), and happiness (H) subscales of MVS. The mean score of EC was calculated at 3.90, and this means that prospective teachers mildly agreed with ecocentric value judgments such as "we are approaching the limit of the number of people the earth can support". In turn, the mean scores of AC were 3.13, and it means that prospective teachers were unsure about anthropocentric value judgments such as "humans have the right to modify the natural environment to suit their needs". For all items of NEPS, the mean score was found 3.55 which corresponds to mildly agree on options. On the other hand, the mean scores MVS total, and MVS' subscales were ranged from 2.60 (centrality) to 2.80 (happiness). These results revealed that the materialist values of the prospective teachers were not very strong, and it was to draw attention that they were unsure about materialistic thoughts.

Table 3

The Descriptive Statistics of NEP and MVS Dimensions

\begin{tabular}{lccccc}
\hline Dimensions & N & Minimum & Maximum & Mean & Std. Deviation \\
\hline Eco-centric (EC) & 685 & 1.13 & 5.00 & 3.90 & .56 \\
Anthropocentric (AC) & 685 & 1.43 & 5.00 & 3.13 & .55 \\
NEPS Total & 685 & 1.60 & 4.87 & 3.55 & .39 \\
Success (S) & 685 & 1.00 & 5.00 & 2.60 & .66 \\
Centrality (C) & 685 & 1.14 & 5.00 & 2.59 & .71 \\
Happiness (H) & 685 & 1.00 & 1.89 & 2.80 & .72 \\
MVS Total & 685 & 1.00 & 4.39 & 2.65 & .39 \\
\hline
\end{tabular}

\section{The Relation of NEPS And MVS Scores with Demographic Variables}

In terms of the variables of gender, level of grade, and environmental education, The Mann-Whitney U test was conducted to analyze whether there were statistically significant differences between some independent samples. As shown in Table 4, there was no significant difference by gender for NEPS total and subscale scores. However, there was a significant difference between males and females in success 
and happiness subscales of MVS. For the success subscale that included statements such as "tending to judge their own and others' success by the number and quality of possessions accumulated", the test result indicated that the materialist values of men $(M d n=2.67)$ were stronger than of women $(M d n=2.50) . U=40954.5, p=.03$. Similarly, for the happiness subscale that includes such "viewing possessions and their acquisition as essential to their satisfaction and happiness", the test result indicated that the materialist values of men $(\mathrm{Mdn}=3.00)$ were stronger than of women $(\mathrm{Mdn}=2.80), \mathrm{U}=39221.5, \mathrm{p}=.00$.

Table 4

The Mann-Whitney U Test Results of Both Scale Dimensions by Gender

\begin{tabular}{clcccrcccc}
\hline Dimensions & Gender & n & Mdn & $\begin{array}{c}\text { Mean } \\
\text { Rank }\end{array}$ & $\begin{array}{c}\text { Sum of } \\
\text { Ranks }\end{array}$ & $\boldsymbol{U}$ & $\mathbf{z}$ & $\boldsymbol{p}$ \\
\hline Eco-centric & Male & 182 & 4.00 & 352.23 & 64105.50 & 44093.5 & -.74 & .46 \\
& Female & 503 & 3.88 & 339.66 & 170849.50 & & & \\
Anthropocentric & Male & 182 & 3.14 & 363.70 & 66194.00 & 42005.0 & -1.65 & .09 \\
& Female & 503 & 3.14 & 335.51 & 168761.00 & & & \\
NEPS Total & Male & 182 & 3.60 & 358.93 & 65325.00 & 42874.0 & -1.27 & .20 \\
& Female & 503 & 3.53 & 337.24 & 169630.00 & & & \\
\hline Success (S) & Male & 182 & 2.67 & 369.48 & 66146.00 & \multirow{2}{*}{42053.5} & -2.11 & $.03 *$ \\
& Female & 503 & 2.50 & 333.42 & 168809.50 & & & \\
Centrality (C) & Male & 182 & 2.43 & 320.43 & 62068.50 & 45415.5 & -1.80 & .07 \\
& Female & 503 & 2.59 & 351.17 & 172886.50 & & & \\
Happiness (H) & Male & 182 & 3.00 & 379.00 & 68712.00 & 39487.0 & -2.88 & $.00^{*}$ \\
& Female & 503 & 2.80 & 329.98 & 166243.00 & & & \\
MVS Total & Male & 182 & 2.66 & 356.22 & 67523.00 & \multirow{2}{*}{40676.0} & -1.05 & .29 \\
& Female & 503 & 2.61 & 338.22 & 167432.00 & & \\
\hline
\end{tabular}

The pre-service teachers who participated in this study were studying in the first $(n=336)$ and last $(n=349)$ grade level across different teaching departments at a Faculty of Education. The Mann Whitney $U$ test results summarized in Table 5 revealed the mean scores of the first-grade levels were calculated as being higher than those of last-grade levels in all dimensions of two scales, except eco-centric and happiness subscales. In other words, anthropocentric values and materialistic values of those at the first-grade level are stronger than those in the last grade level. However, the differences between scores in the dimensions of anthropocentric, success, and centrality were statistically significant. Remarkably, materialistic values in the success subscale and centrality subscale included statements such as "placing possessions and their acquisition at the center of their lives" were stronger in the first year of undergraduate education. Likewise, there was a significant difference between the first (Mdn=2.67 for MVS, and Mdn= 3.60 for NEPS) and last grades (Mdn= 2.61 for MVS, and Mdn=3.53 for NEPS) for MVS ( $U=51336, p=.00)$, and NEPS $(\mathrm{U}=53331.5, \mathrm{p}=.04)$ scores.

An Environmental Education Course (EEC) is one of the general culture courses in the departments of Social Sciences Teaching (SST), Primary School Teaching (PST), and Science Teaching (ST) of some of the Faculties of Education at universities in Turkey. So, the participants were asked whether they took any EEC. 
Özdemir, N. (2020). An Investigation of The Relationship Between Ecological and Materialistic.....

Table 5

The Mann-Whitney U Test Results of Both Scale Dimensions by Level of Grade

\begin{tabular}{|c|c|c|c|c|c|c|c|c|}
\hline Dimensions & $\begin{array}{l}\text { Grade } \\
\text { level. }\end{array}$ & $\mathbf{N}$ & Mdn & $\begin{array}{l}\text { Mean } \\
\text { Rank }\end{array}$ & $\begin{array}{l}\text { Sum of } \\
\text { Ranks }\end{array}$ & $\boldsymbol{U}$ & $\mathbf{z}$ & $p$ \\
\hline \multirow{2}{*}{ Eco-centric } & 1 & 336 & 3.88 & 333.73 & 112133.5 & \multirow{2}{*}{55517.5} & \multirow{2}{*}{-1.23} & \multirow{2}{*}{.23} \\
\hline & 4 & 349 & 4.00 & 351.92 & 122821.5 & & & \\
\hline \multirow[t]{2}{*}{ Anthropocentric } & 1 & 336 & 3.14 & 369.74 & 124233.5 & \multirow{2}{*}{49646.5} & \multirow{2}{*}{-3.48} & \multirow{2}{*}{$.00^{*}$} \\
\hline & 4 & 349 & 3.00 & 317.25 & 110721.5 & & & \\
\hline \multirow[t]{2}{*}{ NEPS Total } & 1 & 336 & 3.60 & 358.78 & 120548.5 & \multirow{2}{*}{53331.5} & \multirow{2}{*}{-2.05} & \multirow{2}{*}{$.04^{*}$} \\
\hline & 4 & 349 & 3.53 & 327.81 & 114406.5 & & & \\
\hline \multirow[t]{2}{*}{ Success (S) } & 1 & 336 & 2.67 & 362.99 & 121964.0 & \multirow{2}{*}{51916} & \multirow{2}{*}{-2.60} & \multirow{2}{*}{$.00^{*}$} \\
\hline & 4 & 349 & 2.50 & 323.76 & 112991.0 & & & \\
\hline \multirow[t]{2}{*}{ Centrality (C) } & 1 & 336 & 2.71 & 373.65 & 125548.0 & \multirow{2}{*}{48332} & \multirow{2}{*}{-3.98} & \multirow{2}{*}{$.00^{*}$} \\
\hline & 4 & 349 & 2.43 & 313.49 & 109407.0 & & & \\
\hline \multirow[t]{2}{*}{ Happiness $(\mathrm{H})$} & 1 & 336 & 2.80 & 343.26 & 115336.5 & \multirow{2}{*}{58543.5} & \multirow{2}{*}{-.03} & \multirow{2}{*}{.97} \\
\hline & 4 & 349 & 2.80 & 342.75 & 119618.5 & & & \\
\hline \multirow[t]{2}{*}{ MVS Total } & 1 & 336 & 2.67 & 364.71 & 122544.0 & \multirow{2}{*}{51336} & \multirow{2}{*}{-2.82} & \multirow{2}{*}{$.00^{*}$} \\
\hline & 4 & 349 & 2.61 & 322.09 & 112411.0 & & & \\
\hline
\end{tabular}

Table 6 displays that a total of 330 respondents answered this question as "yes", whereas 355 of them answered as "no" to it. The mean scores of the eco-centric subscale of those who participated in EEC $(M d n=4.00)$ were higher than those who did not $(\mathrm{Mdn}=3.88)$. However, the analysis results indicated that there was no significant difference between "yes" and "no" answers, $U=54415.5, p=.11$. In contrast, there was a significant difference between "yes" $(\mathrm{Mdn}=3.00)$ and "no" $(M d n=3.14)$ answers in the anthropocentric sub-scale, $(U=49905, p=.00)$. Similar to these results, there were significant differences for MVS total $(U=50856.5, p=$ $.00)$, success $(U=51002.5, p=.00)$, and centrality $(U=50246.5, p=.00)$ subscales. These results suggested that the materialist tendencies of those who did not participate in this course were stronger.

Table 6

The Mann-Whitney U Test Results of Both Scale Dimensions by Environmental Education Course (EEC)

\begin{tabular}{|c|c|c|c|c|c|c|c|c|}
\hline Dimensions & Response & $\mathbf{N}$ & Mdn & $\begin{array}{l}\text { Mean } \\
\text { Rank }\end{array}$ & $\begin{array}{l}\text { Sum of } \\
\text { Ranks }\end{array}$ & $\boldsymbol{U}$ & $Z$ & $p$ \\
\hline \multirow[t]{2}{*}{ Eco-centric } & Yes & 330 & 4.00 & 355.60 & 117349.5 & \multirow{2}{*}{54415.5} & \multirow{2}{*}{-1.613} & \multirow{2}{*}{.11} \\
\hline & No & 355 & 3.88 & 331.28 & 117605.5 & & & \\
\hline \multirow[t]{2}{*}{ Anthropocentric } & Yes & 330 & 3.00 & 316.73 & 104520.0 & \multirow{2}{*}{49905.0} & \multirow{2}{*}{-3.362} & \multirow{2}{*}{$.00 *$} \\
\hline & No & 355 & 3.14 & 367.42 & 130435.0 & & & \\
\hline \multirow[t]{2}{*}{ NEPS Total } & Yes & 330 & 3.53 & 329.43 & 108712.5 & \multirow[b]{2}{*}{54097.5} & \multirow[b]{2}{*}{-1.734} & \multirow[b]{2}{*}{.08} \\
\hline & No & 355 & 3.60 & 355.61 & 126242.5 & & & \\
\hline \multirow[t]{2}{*}{ Success (S) } & Yes & 330 & 2.50 & 320.05 & 105617.5 & \multirow{2}{*}{51002.5} & \multirow[t]{2}{*}{-2.936} & \multirow{2}{*}{$.00^{*}$} \\
\hline & No & 355 & 2.67 & 364.33 & 129337.5 & & & \\
\hline \multirow[t]{2}{*}{ Centrality (C) } & Yes & 330 & 2.43 & 317.76 & 104861.5 & \multirow{2}{*}{50246.5} & \multirow{2}{*}{-3.225} & \multirow{2}{*}{$.00 *$} \\
\hline & No & 355 & 2.57 & 366.46 & 130093.5 & & & \\
\hline \multirow[t]{2}{*}{ Happiness $(\mathrm{H})$} & Yes & 330 & 2.80 & 332.92 & 109864.0 & \multirow{2}{*}{55249.0} & \multirow{2}{*}{-1.290} & \multirow{2}{*}{.19} \\
\hline & No & 355 & 2.80 & 352.37 & 125091.0 & & & \\
\hline \multirow[t]{2}{*}{ MVS Total } & Yes & 330 & 2.56 & 319.61 & 105471.5 & \multirow{2}{*}{50856.5} & \multirow{2}{*}{-2.984} & \multirow{2}{*}{$.00^{*}$} \\
\hline & No & 355 & 2.61 & 364.74 & 129483.5 & & & \\
\hline
\end{tabular}

Table 7a displays the Kruskal Wallis $\mathrm{H}(\mathrm{KWH})$ results according to departments. This analysis result revealed that there was a significant difference among 5 
departments only in the eco-centric subscale of NEPS, $X^{2}(s \mathrm{~d}=4, \mathrm{n}=685)=9.55, \mathrm{p}=.04$. The mean rank of eco-centric scores was ranked between 364.44 (SST $n=115)$ and 304,36 (MT n=136). Group scores were compared with the Mann Whitney U test to determine which groups differed. These test results indicated that these differences were between SST and MT groups, between ST and MT. This result recalls that the eco-centric values of prospective Social Studies and Science teachers have stronger than prospective teachers in other departments.

Table $7 \mathrm{a}$

The Kruskal Wallis H Results of NEP Dimensions for Department Variable

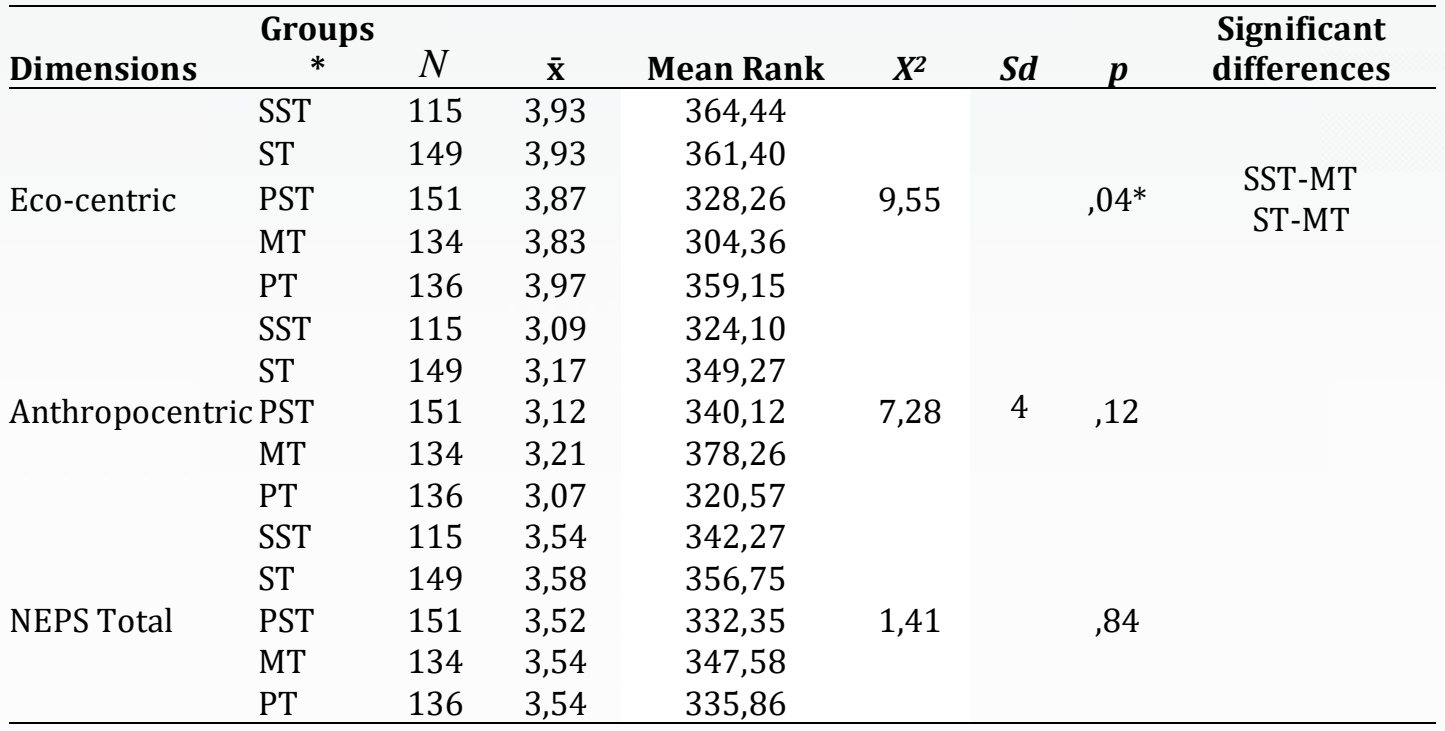

*Social Studies Teachings (SST), science teaching, (ST), primary school teaching (PST), mathematic teaching (MT), preschool teaching (PT).

The KWH result indicated that there were significant differences among departments for MVS total and sub-scales of MVS. The mean rank of success subscale was between maximum 424.00 (SST) and minimum 309.25 (ST), and the U test result for this sub-scale showed that significant differences were between SST and other groups, and ST and MT, $X^{2}(s d=4, n=685)=28.92 \mathrm{p}=.00$. In other words, materialist tendencies on the success of SST were stronger than other groups, while ST was weaker than other groups. In the centrality sub-scale, similarly, the highest mean rank was calculated in the SST group (Mean Rank=437.9), whereas the lowest mean rank was calculated in the ST group (Mean Rank= 282.36). This difference between the mean scores of both SST and ST groups and the mean scores of other groups were found to be statistically significant, $X^{2}(s \mathrm{~d}=4, \mathrm{n}=685)=42.65, \mathrm{p}=.00$. The analysis results for happiness subscale $\left(X^{2}(\mathrm{~s} d=4, \mathrm{n}=685)=37.62, p=.00\right)$ and MVS total scores $\left(X^{2}\right.$ $(\mathrm{sd}=4, \mathrm{n}=685)=52.90, p=.00)$ were similar to success and centrality scores (Table 7b). 
Özdemir, N. (2020). An Investigation of The Relationship Between Ecological and Materialistic.....

Table $7 \mathrm{~b}$

The Kruskal Wallis H Results of MVS Dimensions for Department Variable

\begin{tabular}{|c|c|c|c|c|c|c|c|}
\hline \multirow{5}{*}{ Success (S) } & SST & 115 & 2,89 & 424,00 & \multirow{5}{*}{28,92} & \multirow{5}{*}{, $00^{*}$} & \multirow{4}{*}{$\begin{array}{l}\text { SST- all groups } \\
\text { ST-MT }\end{array}$} \\
\hline & ST & 149 & 2,47 & 309,25 & & & \\
\hline & PST & 151 & 2,58 & 331,59 & & & \\
\hline & MT & 134 & 2,61 & 357,76 & & & \\
\hline & PT & 136 & 2,49 & 309,61 & & & \\
\hline \multirow{4}{*}{ Centrality (C) } & SST & 115 & 2,98 & 437,90 & \multirow{6}{*}{42,65} & \multirow{5}{*}{, $00^{*}$} & \\
\hline & ST & 149 & 2,37 & 282,36 & & & SDI- all groups \\
\hline & PST & 151 & 2,56 & 332,86 & & & ST-PST \\
\hline & MT & 134 & 2,51 & 326,26 & & & $\begin{array}{l}\text { ST-MT } \\
\text { CT DT }\end{array}$ \\
\hline \multirow{6}{*}{$\begin{array}{l}\text { Happiness } \\
\text { (H) }\end{array}$} & PT & 136 & 2,61 & 356,94 & & & \\
\hline & SST & 115 & 3,06 & 413,93 & & 4 & \\
\hline & ST & 149 & 2,55 & 270,58 & \multirow{4}{*}{37,62} & \multirow{4}{*}{, $00^{*}$} & $\begin{array}{l}\text { SS1-all groups } \\
\text { ST-PST }\end{array}$ \\
\hline & PST & 151 & 2,87 & 364,14 & & & $\begin{array}{l}\text { CT-MT } \\
\text { ST-MS }\end{array}$ \\
\hline & MT & 134 & 2,82 & 352,01 & & & ST-PT \\
\hline & PT & 136 & 2,77 & 330,02 & & & \\
\hline \multirow{5}{*}{ MVS Total } & SST & 115 & 2,97 & 448,33 & \multirow{5}{*}{52,90} & \multirow{5}{*}{, $00^{*}$} & \\
\hline & ST & 149 & 2,46 & 271,56 & & & SST- all groups \\
\hline & PST & 151 & 2,64 & 343,97 & & & $\begin{array}{l}\text { SI-PSI } \\
\text { STMT }\end{array}$ \\
\hline & MT & 134 & 2,63 & 346,28 & & & $\begin{array}{l}\text { S1-1VI } \\
\text { ST_PT }\end{array}$ \\
\hline & PT & 136 & 2,61 & 327,89 & & & \\
\hline
\end{tabular}

*Social Studies Teachings (SST), science teaching, (ST), primary school teaching (PST), $\mathrm{m}$ athematic teaching (MT), preschool teaching (PT).

\section{The Correlations Relation to NEPS And MVS Scores, And EE Variable}

The Spearman correlation analyses were computed among scales and EE variables for 380 participants. As shown in Table 8, the results suggest that 19 out of 27 correlations were statistically significant. The Spearman's rho revealed statistically significant negative correlations between EC and AC sub-scales of NEPS $(\mathrm{rs}[380]=-.590, \mathrm{p}<.01)$. Similarly, there were a significant negative correlation between EC with MVS' subscales S $\left(\mathrm{rs}_{[380]}=-.114, \mathrm{p}<.01\right)$ and C $\left(\mathrm{rs}_{[380]}=-.161, \mathrm{p}<\right.$ $.01)$; between MVS total and EC $\left(\mathrm{rs}_{[380]}=-.152, \mathrm{p}<.01\right)$. However, the analysis results indicated nonsignificant correlation between EC sub-scale and EE ( $\mathrm{rs}$ [380] = $.062, \mathrm{p}>.05$ ). In return, these significant correlations were positive for AC sub-scale of NEPS, while there was a negative significant negative correlation between AC and $\mathrm{EE},(\mathrm{rs}[380]=-.129, \mathrm{p}<.01)$. Although there was a negative correlation between NEPS and MVS, and a positive correlation between NEPS and EE, these correlations were not statistically significant. And, conversely, there was a significant negative correlation between MVS and EE $\left(\mathrm{rs}_{[380]}=-.114, \mathrm{p}<.01\right)$. 
Table 8

The Spearman Correlation Coefficients Between Variables

\begin{tabular}{|c|c|c|c|c|c|c|c|c|}
\hline & EC & AC & $S$ & C & H & NEPS & MVS & EE \\
\hline EC & 1.000 & $-.590 * *$ & $-.114^{* *}$ & $-.161^{* *}$ & -.056 & $.703^{* *}$ & $-.152^{* *}$ & .062 \\
\hline $\mathrm{AC}$ & & 1.000 & $.145^{* *}$ & $.097^{*}$ & $.076^{*}$ & $.666^{* *}$ & $.124^{* *}$ & $-.129^{* *}$ \\
\hline S & & & 1.000 & $.506^{* *}$ & $.439^{* *}$ & .008 & $.799^{* *}$ & $-.112^{* *}$ \\
\hline C & & & & 1.000 & $.357^{* *}$ & -.071 & $.817^{* *}$ & $-.123^{* *}$ \\
\hline $\mathrm{H}$ & & & & & 1.000 & .014 & $.711^{* *}$ & .049 \\
\hline NEPS & & & & & & 1.000 & -.039 & .066 \\
\hline MVS & & & & & & & 1.000 & $-.114^{* *}$ \\
\hline
\end{tabular}

${ }^{* *} p<0.01 ;{ }^{*} p<0.05$

\section{Discussion}

The research findings revealed that the eco-centric values of the prospective teachers were stronger than the anthropocentric values. On the other hand, the results of the analysis of MVS showed that the participants were unsure about materialism. The results of the analysis of the sub-dimensions of both scales proved that there were significant relationships for some of the independent variables. According to the analysis results of NEPS, the ecological attitudes of the participants did not differ statistically significant in the context of gender. This result is consistent with the results of some studies used NEPS to measure the environmental attitudes of Turkish undergraduates (Alagöz \& Akman, 2016; Sever \& Yalçınkaya, 2012; Tekin, 2012; Yalçınkaya, Karataş, \& Talas, 2014). However, in a review of Zelezny, Chua, and Aldrich (2000b) focused on gender differences in environmentalism, it was reported that in the majority of studies which used NEPS, the environmental concerns of women were greater than men. However, only a few studies found there to be no significant difference between males and females about environmental concern; and no study found that males had significantly greater environmental concern than women. In the literature since the 1990s, similar results were found. There were some studies suggesting that women hold stronger pro-environmental values, beliefs, and attitudes, and participate more actively in the private sphere of environmental behaviors than men (Blocker \& Eckberg, 1997; Casey \& Scott, 2006; Davidson \& Freudenburg, 1996; Erkal et al., 2012; Müderrisoglu \& Altanlar, 2011; Taşkın, 2009; Xiao, Dunlap, \& Hong, 2019). On the other hand, some theories have been developed to explain the relationship between gender and environmental attitudes or behaviors, albeit in a limited number. of these theories, the most commonly used theory is related to processes of socialization and resultant gender roles. According to this theory, gender differences in environmental attitudes and behaviors may be the product of socialization rather than biological differences (Davidson \& Freudenburg, 1996; Stern, Dietz, \& Kalof, 1993). In almost all cultures, females are socialized as more interdependent, compassionate, nurturing, cooperative, and in caregiving roles, whereas males are socialized as more independent and competitive (Dietz, Kalof, \& Stern, 2002; Smith, 2001; Vicente-Molina, Fernández-Sainz, \& Izagirre-Olaizola, 2018; Zelezny, Chua, \& Aldrich, 2000a). However, meta-analytic research that compares past and present 
studies on gender and environmental attitudes and behaviors is needed to clarify the emergence of change over time so environmental attitudes may have changed from past to present (Zelezny et al., 2000b). Moreover, investigating the relationship between environmental attitudes and gender in 14 countries, Davidson and Freudenburg (1996) reported that gender differences in attitudes towards the environment are not universal. According to the findings of some research in China, used in support of this thesis, there were no significant difference in proenvironmental attitudes between Chinese men and women, whereas educated Chinese men may have stronger pro-environmental attitudes than women (Shields \& Zeng, 2012; Xiao et al., 2019; Xiao \& Hong, 2010, 2018). Logically, such findings suggest that the socialization theory to explain the relationship between environmentalism and gender may not be applicable in China or all of the other cultures.

The low MVS scores may be related to the fact that the participants were students and most of them did not have a regular income. However, the findings related to MVS demonstrated that there were differences in happiness and success subscales in terms of gender. In other words, the tendency to accept property acquisition as a source of happiness and success was stronger in men than in women. This result was consistent with the findings of some previous studies (Felix et al., 2013; Kamineni, 2005; Karabati \& Cemalcilar, 2010; Segal \& Podoshen, 2013; Workman \& Lee, 2011). On the subject, Browne and Kaldenberg (1997) reported that males may be more likely to feel that owning material goods increases their happiness. In recent years, there has been a significant amount of literature that examines the relationship between gender and materialism. The results of such studies revealed that the relationship between gender and materialism was a controversial issue. In some of these studies, there was no significant relationship between gender and materialism (Burroughs \& Rindfleisch, 2002; Dittmar, 2005; Handa \& Khare, 2013; Richins \& Dawson, 1992; Saunders, 2007), whereas, in other studies, females scored higher on materialism than males, in contrast to many studies that reported that men were more materialistic than women (Burroughs \& Rindfleisch, 2002; 0'Cass, 2001, 2004; Workman \& Lee, 2011).

The research findings suggest that there may be a relationship between environmental education and environmental attitudes or materialist values. Significant differences between the first and last grades in the context of anthropocentric, centrality, and success scores may be related to environmental literacy. There was some evidence suggesting this in the research findings. Firstly, the environmental education course was one of the courses in third or fourth-grade levels in some departments of the Faculty of Education where participants were studying. The results of the analysis for anthropocentric, centrality and success scores revealed there were significant differences between those who took environment course and those who did not. Moreover, the results from the correlation analysis proved there was a negative correlation with the environmental education variable of anthropocentric, centrality, and success scores. Secondly, the 
lowest eco-centric and the highest anthropocentric scores were those of the prospective mathematics teachers. This result may be related to the absence of any course on environmental education among the available courses in the curriculum of the Mathematics teaching department. Also, most of the prospective Mathematics teachers who participated in the study reported that they had not previously attended any courses on environmental education. Thirdly, the results of MVS revealed that the highest scores were noteworthy for prospective Social Sciences teachers when compared with their peers in other departments. This result can partly be explained with environmental literacy because, in this department, the MVS scores of those participated in environmental education course were lower than of those who did not. On the other hand, when the groups were compared based on the department variable, significant differences between MVS scores and environmental education variables were determined only for the social studies teacher group. In line with this, some of the previous studies reported that there was a negative correlation between environmental beliefs and materialist tendencies (Andersson \& Nässén, 2016; Callicott, 2004; Hurst et al., 2013; Kilbourne \& Pickett, 2008), whereas some of them have reported a positive relationship between environmental literacy and environmental attitudes (Koç \& Karatekin, 2013; Pe'er, Goldman, \& Yavetz, 2007; Yalçınkaya \& Çetin, 2018).

\section{Conclusion}

As put forward by previous studies examining the relationship between the level of income and materialism (Dávila, Casabayó, \& Singh, 2017; Goldberg, Gorn, Peracchio, \& Bamossy, 2003; La Barbera \& Gürhan, 1997; Larsen, Sirgy, \& D. Wright, 1999), and between the level of income and environmental attitudes (Arcury, 1990; Martinsson, Lundqvist, \& Sundström, 2011; Özden, 2008; Scott \& Willits, 1994), people in low-income households can be more materialistic and weaker environmental attitudes than those in higher-income families. Therefore, the results of the present study can partly be related to the level of family income. However, it was not possible to make a comparison among lower-middle and upper-income groups because the students participating in the study reported their families' monthly income as $\$ 600$ or less. Therefore, the relationship between materialism and environmentalism with examples from different income groups may be the subject of research for further studies. The results of the study shown that a weak negative correlation among eco-centric values, environmental education, and materialistic values. These results suggest that if the environmental values of the individuals are high, their materialistic values may be low; also, environmental literacy may be an important determinant in this regard. Undoubtedly, it is not possible to generalize with the findings of this research, therefore, different research findings are needed to support this subject. However, if environmental literacy is "the priority of priorities" for a sustainable environment (Fien \& Tilbury, 1996; Tilbury, 1993; UNESCO-UNEP, 1990), then "environmental education at primary, secondary and tertiary levels have an important role to play in the development of students who are capable of understanding and who are motivated to respond to 
the issues which give rise to an environmental crisis" (Cutter \& Smith, 2001, p. 47). In this context, it is an important issue that teachers who will train the next generation are known to have environmental literacy, pro-environmental attitudes, and behaviors. However, in the curriculums of most education faculties in Turkey, courses on environmental education are among the elective courses in curriculums of most departments. Furthermore, in some departments, such as mathematics education, the prospective teacher does not have any lessons about the environmental education.

Another important issue is related to the content and conduct of environmental education courses (Uzun \& Sağlam, 2007). Providing environmental education with an understanding about a sustainable world at all levels of education, from primary education to university, can make people more conscious and more sensitive about the environment. Therefore, people can develop pro-environmental attitudes and behaviors (Çolakoğlu, 2010). As might be expected, there are different views about the proper role of environmental education. In this vein, some approaches have been developed such as education about the environment, education in (or through) the environment, and education for the environment (Cutter \& Smith, 2001). As is clear from research on the subject, the content of courses dealing with environmental education in the majority of education faculties in Turkey, and teaching strategies used in this course are conducted as "education about the environment" (Ballantyne \& Packer, 1996; Bentham et al., 2015; Hungerford \& Volk, 1990; Özdemir, 2010; Stevenson, 2007; Ünal \& Dımışkı, 1998). The primary objective of environmental education should be to educate individuals who do not hold their personal interest's superior to those of nature, and who have a universal ethical understanding and a nature-centered world view. It is considered that these objectives can be achieved to a large extent through "education for the environment" (Cutter \& Smith, 2001; Fien, 2000). In this context, if teachers at all levels of education are "trained for the environment", the education system can be expected to produce environmentally friendly citizens. Hence, the materialist values of environmentally sensitive citizens may not be strong. However, this assumption needs to be supported by future studies that focus on the relationship between materialist values and environmental values.

\section{References}

Achim, M., Stan, A., \& Dragolea, L. (2018). Study on the importance of sustainable development strategy for a community. Journal of Environmental Protection and Ecology, 19(1), 152-162.

Alagöz, B., \& Akman, O. (2016). Anthropocentric or ecocentric environmentalism? Vews of university students. Higher Education Studies, 6(4), 34-53.

Albayrak, T., Caber, M., Moutinho, L., \& Herstein, R. (2011). The influence of skepticism on green purchase behavior. International Journal of Business and Social Science, 2(13), 189-197.

Alwitt, L. F., \& Pitts, R. E. (1996). Predicting purchase intentions for an environmentally sensitive product. Journal of Consumer Psychology, 5(1), 49-64. 
Andersson, D., \& Nässén, J. (2016). Should environmentalists be concerned about materialism? An analysis of attitudes, behaviors and greenhouse gas emissions. Journal of Environmental Psychology, 48, 1-11.

Arcury, T. A. (1990). Environmental attitude and environmental knowledge. Human Organization, 49(4), 300-304.

Atasoy, E. (2006). Education for Environmental, Child-Nature Interaction (in Turkish). Bursa: Ezgi Kitapevi.

Aytaç, M., \& Öngen, B. (2012). Doğrulayıcı faktör analizi ile yeni çevresel paradigma ölçeğinin yapı geçerliliğinin incelenmesi. İstatistikçiler Dergisi: Ístatistik ve Aktüerya, 5(1), 14-22.

Ballantyne, R., \& Packer, J. (1996). Teaching and learning in environmental education: Developing environmental conceptions. The Journal of Environmental Education, 27(2), 25-32.

Barr, S. (2007). Factors influencing environmental attitudes and behaviors: A UK case study of household waste management. Environment and Behavior, 39(4), 435-473.

Belk, R. W. (1985). Materialism: Trait aspects of living in the material world. Journal of Consumer Research, 12(3), 265-280.

Bentham, H., Sinnes, A., \& Gjøtterud, S. (2015). A teacher education for sustainable development system: An institutional responsibility. International Journal of Higher Education, 4(4), 158-177.

Blake, J. (1999). Overcoming the 'value-action gap'in environmental policy: Tensions between national policy and local experience. Local Environment, 4(3), 257-278.

Blocker, T. J., \& Eckberg, D. L. (1997). Gender and environmentalism: Results from the 1993 general social survey. Social Science Quarterly, 78(4), 841-858.

Bonnes, M., \& Secchiaroli, G. (1995). Environmental psychology: a psycho-social introduction. London, Thousand Oaks, New Delhi: Sage Publications.

Browne, B. A., \& Kaldenberg, D. O. (1997). Conceptualizing self-monitoring: Links to materialism and product involvement. Journal of Consumer Marketing, 14(1), 31-44.

Burgess, J., Harrison, C. M., \& Filius, P. (1998). Environmental communication and the cultural politics of environmental citizenship. Environment and Planning A, 30(8), 1445-1460.

Burroughs, J. E., \& Rindfleisch, A. (2002). Materialism and well-being: A conflicting values perspective. Journal of Consumer Research, 29(3), 348-370.

Callicott, J. (2004). Explicit and implicit values in the ESA. In G. Davies, Heal, and Scott (Eds.), The endangered species act at thirty: Retrospect and prospects. Washington, DC: Island Press.

Carter, R. L., \& Simmons, B. (2010). The history and philosophy of environmental education. In Alec M. Bodzin, Beth Shiner Klein, \& S. Weave (Eds.), The inclusion of environmental education in science teacher education (pp. 3-16). Netherlands: Springer.

Casey, P. J., \& Scott, K. (2006). Environmental concern and behavior in an Australian sample within an ecocentric-anthropocentric framework. Australian Journal of Psychology, 58(2), 57-67.

Çolakoğlu, E. (2010). Haklar söyleminde çevre eğitiminin yeri ve Türkiye'de çevre eğitiminin anayasal dayanakları. TBB Dergisi, 88, 151-171. 
Cutter, A., \& Smith, R. (2001). Gauging primary school teachers' environmental literacy: An issue of 'priority'. Asia Pacific Education Review, 2(2), 45-60.

Davidson, D. J., \& Freudenburg, W. R. (1996). Gender and environmental risk concerns: A review and analysis of available research. Environment and Behavior, 28(3), 302-339.

Dávila, J. F., Casabayó, M., \& Singh, J. J. (2017). A world beyond family: How external factors impact the level of materialism in children. Journal of Consumer Affairs, 51(1), 162182.

Dietz, T., Kalof, L., \& Stern, P. C. (2002). Gender, values, and environmentalism. Social Science Quarterly, 83(1), 353-364.

Dittmar, H. (2005). Compulsive buying-a growing concern? An examination of gender, age, and endorsement of materialistic values as predictors. British Journal of Psychology, 96(4), 467-491.

Dunlap, R. E., \& Van Liere, K. D. (1978). The "new environmental paradigm". The Journal of Environmental Education, 9(4), 10-19.

Dunlap, R. E., Van Liere, K. D., Mertig, A. G., \& Jones, R. E. (2000). New trends in measuring environmental attitudes: measuring endorsement of the new ecological paradigm: a revised NEP scale. Journal of Social Issues, 56(3), 425-442.

Erdoğan, N. (2009). Testing the new ecological paradigm scale: Turkish case. African Journal of Agricultural Research, 4(10), 1023-1031.

Erkal, S., Kiliç, I., \& Sahin, H. (2012). Comparison of environmental attitudes of university students determined via the new environmental paradigm scale according to the students' personal characteristics. Eurasian Journal of Educational Research, 49, 2139.

Felix, R., Ahmed, Z. U., \& Hinck, W. (2013). Gender issues in consumer materialism: The case of Mexico. Journal of Transnational Management, 18(2), 82-100.

Fien, J. (2000). Education for the environment: A critique- an analysis. Environmental Education Research, 6(2), 179-192.

Fien, J., \& Tilbury, D. (1996). Learning for a sustainable environment: An agenda for teacher education in Asia and The Pacific. Bangkok: UNESCO Principal Regional Office for Asia and the Pacific.

Fishbein, M., \& Ajzen, I. (1980). Understanding attitudes and social behavior. Englewood Cliffs, NJ: Prentice Hall.

Fraenkel, J. R., Wallen, N. E., \& Hyun, H. H. ( 1993). How to design and evaluate research in education. New York: McGraw-Hill.

Goldberg, M. E., Gorn, G. J., Peracchio, L. A., \& Bamossy, G. (2003). Understanding materialism among youth. Journal of Consumer Psychology, 13(3), 278-288.

Handa, M., \& Khare, A. (2013). Gender as a moderator of the relationship between materialism and fashion clothing involvement among Indian youth. International Journal of Consumer Studies, 37(1), 112-120.

Hines, J. M., Hungerford, H. R., \& Tomera, A. N. (1987). Analysis and synthesis of research on responsible environmental behavior: A meta-analysis. The Journal of Environmental Education, 18(2), 1-8.

Hirsh, J. B., \& Dolderman, D. (2007). Personality predictors of consumerism and environmentalism: A preliminary study. Personality and Individual Differences, 43(6), 1583-1593. 
Hungerford, H. R., \& Volk, T. L. (1990). Changing learner behavior through environmental education. The Journal of Environmental Education, 21(3), 8-21.

Hurst, M., Dittmar, H., Bond, R., \& Kasser, T. (2013). The relationship between materialistic values and environmental attitudes and behaviors: A meta-analysis. Journal of Environmental Psychology, 36, 257-269.

Justus, J., Colyvan, M., Regan, H., \& Maguire, L. (2009). Buying into conservation: intrinsic versus instrumental value. Trends in Ecology \& Evolution, 24(4), 187-191.

Kamineni, R. (2005). Influence of materialism, gender and nationality on consumer brand perceptions. Journal of Targeting, Measurement and Analysis for Marketing, 14(1), 2532.

Kaptan, S. (1998). Bilimsel araştırma ve istatistik teknikleri. Ankara: Tekışık Web Ofset.

Karabati, S., \& Cemalcilar, Z. (2010). Values, materialism, and well-being: A study with Turkish university students. Journal of Economic Psychology, 31(4), 624-633.

Karasar, N. (2002). Bilimsel araștırma yöntemi (11 Ed.). Ankara: Nobel Yayınevi.

Kemmelmeier, M., Krol, G., \& Kim, Y. H. (2002). Values, economics, and proenvironmental attitudes in 22 societies. Cross-cultural Research, 36(3), 256-285.

Kilbourne, W. E., \& Carlson, L. (2008). The dominant social paradigm, consumption, and environmental attitudes: Can macromarketing education help? Journal of Macromarketing, 28(2), 106-121.

Kilbourne, W., \& Pickett, G. (2008). How materialism affects environmental beliefs, concern, and environmentally responsible behavior. Journal of Business Research, 61(9), 885893.

Koç, H., \& Karatekin, K. (2013). Coğrafya öğretmen adaylarinin çevre okuryazarlık düzeylerinin çeşitli değişkenler açısından incelenmesi. Marmara Coğrafya Dergisi(28), 139-174. Retrieved from https://dergipark.org.tr/tr/download/articlefile/3350

Kollmuss, A., \& Agyeman, J. (2002). Mind the gap: Why do people act environmentally and what are the barriers to pro-environmental behavior? Environmental Education Research, 8(3), 239-260.

La Barbera, P. A., \& Gürhan, Z. (1997). The role of materialism, religiosity, and demographics in subjective well-being. Psychology \& Marketing, 14(1), 71-97.

Larsen, V., Sirgy, M. J., \& D. Wright, N. (1999). Materialism: The construct, measures, antecedents, and consequences. Academy of Marketing Studies Journal, 3(2), 78-110.

Martinsson, J., Lundqvist, L. J., \& Sundström, A. (2011). Energy saving in Swedish households. The (relative) importance of environmental attitudes. Energy Policy, 39(9), 5182-5191.

Materialism. (n.d). In Oxford learner's dictionaries. Retrieved from https://www.oxfordlearnersdictionaries.com/definition/english/materialism?q=m aterialism

Müderrisoglu, H., \& Altanlar, A. (2011). Attitudes and behaviors of undergraduate students toward environmental issues. International Journal of Environmental Science \& Technology, 8(1), 159-168.

O'Cass, A. (2001). Consumer self-monitoring, materialism and involvement in fashion clothing. Australasian Marketing Journal (AMJ), 9(1), 46-60. 
O'Cass, A. (2004). Fashion clothing consumption: antecedents and consequences of fashion clothing involvement. European Journal of Marketing, 38(7), 869-882.

Özdemir, O. (2010). Yeni bir çevre eğitimi perspektifi: Sürdürülebilir gelişme amaçlı eğitim. Eğitim ve Bilim, 32(145), 23-38.

Özden, M. (2008). Environmental awareness and attitudes of student teachers: An empirical research. International Research in Geographical and Environmental Education, 17(1), 40-55. Retrieved from https://www.tandfonline.com/doi/pdf/10.2167/irgee227.0? needAccess $=$ true

Palmer, J. A. (2002). Environmental education in the 21st century: Theory, practice, progress and promise. London and New York: Routledge.

Pe'er, S., Goldman, D., \& Yavetz, B. (2007). Environmental literacy in teacher training: Attitudes, knowledge, and environmental behavior of beginning students. The Journal of Environmental Education, 39(1), 45-59.

Rajecki, D. (1982). Attitudes: themes and advances. Sunderland, MA: Sinauer Associates, Inc.

Retrieved from https://dergipark.org.tr/tr/download/article-file/3296

Richins, M. L., \& Dawson, S. (1992). A consumer values orientation for materialism and its measurement: Scale development and validation. Journal of Consumer Research, 19(3), 303-316.

Richins, M., \& Fournier, S. (1991). Some theoretical and popular notions concerning materialism. Journal of Social Behavior and Personality, 6(6), 403-414.

Rickinson, M. (2001). Learners and learning in environmental education: A critical review of the evidence. Environmental Education Research, 7(3), 207-320.

Robert, K. W., Parris, T. M., \& Leiserowitz, A. A. (2005). What is sustainable development? Goals, indicators, values, and practice. Environment, 47(3), 8-21.

Saunders, S. A. (2007). A snapshot of five materialism studies in Australia. Journal of Pacific Rim Psychology, 1(1), 14-19.

Scott, D., \& Willits, F. K. (1994). Environmental attitudes and behavior: A Pennsylvania survey. Environment and Behavior, 26(2), 239-260.

Segal, B., \& Podoshen, J. S. (2013). An examination of materialism, conspicuous consumption and gender differences. International Journal of Consumer Studies, 37(2), 189-198.

Sever, R., \& Yalçınkaya, E. (2012). Sınıf öğretmeni adaylarının çevresel tutumlarının incelenmesi. Marmara Coğrafya Dergisi, (26), 1-15.

Shamuganathan, S., \& Karpudewan, M. (2015). Modeling environmental literacy of Malaysian pre-university students. International Journal of Environmental and Science Education, 10(5), 757-771.

Shields, T., \& Zeng, K. (2012). The reverse environmental gender gap in China: Evidence from "The China Survey". Social Science Quarterly, 93(1), 1-20.

Smith, D. C. (2001). Environmentalism, feminism, and gender. Sociological Inquiry, 71(3), 314-334.

Sönmez, V., \& Alacapınar, F. G. (2016). Örneklendirilmiş bilimsel araştırma yöntemleri (4 ed.). Ankara: Anı Yayıncılık.

Stern, P. C., Dietz, T., \& Kalof, L. (1993). Value orientations, gender, and environmental concern. Environment and Behavior, 25(5), 322-348. 
Stevenson, R. B. (2007). Schooling and environmental education: Contradictions in purpose and practice. Environmental Education Research, 13(2), 139-153.

Taşkın, 0. (2009). The environmental attitudes of Turkish senior high school students in the context of postmaterialism and the new environmental paradigm. International Journal of Science Education, 31(4), 481-502.

Tekin, E. (2012). Environmental awareness and concerns of pre-service teachers in a private non-profit university (Master dissertation). Bilkent University, Ankara. Retrieved from https://tez.yok.gov.tr/UlusalTezMerkezi/tezSorguSonucYeni.jsp (319547.

Tekin, H. (1996). Eğitimde Ölçme ve Değerlendirme (9 Ed.). Ankara: Yargı Yayınları.

Tilbury, D. (1993). Environmental education: Developing a model for initial teacher education (Doctoral dissertation). University of Cambridge United Kingdom. Retrieved from https://search.proquest.com/docview/2005421168?accountid=16701

Turan, G. (2007). Relationship between materialism and self construals (Doctoral dissertation). Ortadoğu Teknik Üniversitesi, Ankara. Retrieved from https://open.metu.edu.tr/bitstream/handle/11511/16933/index.pdf?sequence=1\& isAllowed $=\mathrm{y}$

Ünal, S., \& Dımışkı, E. (1998). UNESCO uluslararası çevre eğitim programına (IEEP) göre ortaöğretim çevre eğitimi için öğretmenlerin yetiştirilmesi. M. Ü. Atatürk Eğitim Fakültesi Eğitim Bilimleri Dergisi, 30, 299-308.

UNESCO. (2005). Decade of education for sustainable development (2005-2014): international implementation scheme. Retrieved from http://portal.unesco.org/ education/en/

UNESCO-UNEP. (1990). Environmentally educated teachers: The priority of priorities? Connect, 15(1), 1-3. Retrieved from https://unesdoc.unesco.org/ark:/48223/ pf0000153574

United Nations, (1987). Report of the World commission on environment and development our common future, Retrieved from file:///C:/Users/TOSHIBA/Desktop/\%C3\%A7 al\%C4\%B1\%C5\%9Fmalar/R\%C4\%B0GE0/our_common_futurebrundtlandreport1 987.pdf

Uzun, N., \& Sağlam, N. (2007). Orta öğretimde çevre eğitimi ve öğretmenlerin çevre eğitimi programları hakkındaki görüşleri. Eurasian Journal of Educational Research, 26, 176187.

Vicente-Molina, M., Fernández-Sainz, A., \& Izagirre-Olaizola, J. (2018). Does gender make a difference in pro-environmental behavior? The case of the Basque Country University students. Journal of Cleaner Production, 176, 89-98.

Wals, A. E. (2014). Sustainability in higher education in the context of the UN DESD: a review of learning and institutionalization processes. Journal of Cleaner Production, 62, 8-15.

Wheeler, K. (1985). International environmental education: A historical perspective. Environmental Education and Information, 4(2), 144-160.

Workman, J. E., \& Lee, S. H. (2011). Materialism, fashion consumers and gender: A crosscultural study. International Journal of Consumer Studies, 35(1), 50-57.

Wray-Lake, L., Flanagan, C. A., \& Osgood, D. W. (2010). Examining trends in adolescent environmental attitudes, beliefs, and behaviors across three decades. Environment and Behavior, 42(1), 61-85. 
Xiao, C., \& Hong, D. (2010). Gender differences in environmental behaviors in China. Population and Environment, 32(1), 88-104.

Xiao, C., \& Hong, D. (2018). Gender differences in environmental behaviors among the Chinese public: Model of mediation and moderation. Environment and Behavior, 50(9), 975-996.

Xiao, C., Dunlap, R. E., \& Hong, D. (2019). Ecological worldview as the central component of environmental concern: Clarifying the role of the NEP. Society \& Natural Resources, 32(1), 53-72.

Yalçınkaya, E., \& Çetin, 0. (2018). An investigation of secondary school students' environmental attitudes and opinions about environmental education. Review of International Geographical Education Online, 8(1), 125-148. Retrieved from http://web.a.ebscohost.com/ehost/pdfviewer/pdfviewer?vid=0\&sid=cdfac71becf6-4976-8875-27e4aef4af8c\%40sdc-v-sessmgr01

Yalçınkaya, E., Karataş, A., \& Talas, M. (2014). A study on the environmental attitudes of candidate teachers. mediterranean journal of humanities, 9(1), 275-284. Retrieved from https://www.trdizin.gov.tr/publication/show/pdf/paper/TVRrd016azFOUT09

Zelezny, L. C., Chua, P. P., \& Aldrich, C. (2000a). Elaborating on gender differences in environmentalism-statistical data included. Journal of Social Issues, 56(3), 443-445.

Zelezny, L. C., Chua, P. P., \& Aldrich, C. (2000b). New ways of thinking about environmentalism: Elaborating on gender differences in environmentalism. Journal of Social Issues, 56(3), 443-457.

\section{Biographical Statement}

Nevin ÖZDEMİR is associate professor of geography education at Education Faculty of Ondokuz Mayıs University, Samsun, Turkey. She received her bachelor's degree (1986) from Geography Department, Ankara University, and master's degree (1994) from Human and Economic Geography of Atatürk University Social Sciences Institute. She also completed her Ph.D. (2002) in Social Sciences Institute of Ankara University. She is interested in geography education, environmental education, hazard education, experiential learning, learning styles, and attitudes studies in education. 